\title{
The Appeal in the Italian Criminal Legal System: Legislative Reforms and Case Law
}

\author{
L'appello Nel Processo Penale Italiano: Tra Riforme E Prassi \\ Giurisprudenziali
}

\section{Massimo BOLOGNARI ${ }^{1 \oplus}$}

${ }^{1}$ Dr., University of Padova, Padova, Italy

\section{ABSTRACT}

This article deals with the crucial and vital issue of the appeal in the Italian criminal justice system. The first part of this study is focused on the historical framework and the main legislative reforms that have characterized the issue of appellate remedies. After this general overview, the article analyzes the different types of appellate remedies and the fundamental principles that govern them. However, the core of this article is devoted to the appeal, which has recently been affected by important legislative reforms that have reshaped it. After some preliminary remarks regarding the nature of the appeal in the Italian criminal justice system, the work deals with the form of the appeal, identifying the subjects who are entitled to lodge an appeal and the preconditions that justify the filing of it. The article is then focused on the appellate procedure, dedicating particular attention to the renewal of the trial evidentiary hearing in case of appeal of the public prosecutor against a first-instance acquittal. This case of renewal has recently been introduced by the Italian legislator following the case law of the European Court of Human Rights and of the Italian Court of Cassation. After analyzing such issues, this work identifies the outcomes of the appellate procedure. Finally, the article draws some conclusions about the issue of the appeal in light of the recent legislative reforms and case law.

Keywords: Appellate remedies, legislative reform, renewal of the trial evidentiary hearing

\section{ABSTRACT (versione italiana)}

Il presente lavoro analizza il tema dell'appello nel processo penale italiano. La prima parte dell'articolo è dedicata all'analisi delle origini storiche e delle principali riforme che hanno caratterizzato il sistema delle impugnazioni. Dopo questo quadro generale, il lavoro si occupa di individuare le principali caratteristiche e i principi che connotano i diversi mezzi di impugnazione disciplinati dal codice di rito. L'articolo si focalizza poi specificamente sull'appello, che è stato di recente profondamente riformato dal legislatore italiano. Dopo alcune considerazioni preliminari relative alla natura di questo rimedio, sono stati analizzati, alla luce della riforma, gli aspetti formali di tale mezzo di impugnazione, i soggetti che sono legittimati a proporlo e i presupposti che ne giustificano la presentazione. L'articolo si incentra poi sul giudizio di appello, dedicando particolare attenzione alla rinnovazione dell'istruzione dibattimentale in caso di impugnazione del pubblico ministero contro una sentenza assolutoria di primo grado. Si tratta di un istituto che è stato introdotto dal legislatore italiano al fine di conformarsi alla giurisprudenza della Corte europea dei diritti dell'uomo e della Corte di Cassazione. Infine, dopo aver analizzato tali problemi, il lavoro si focalizza sui molteplici esiti del giudizio di secondo grado e prospetta alcune questioni che la riforma pone con riguardo alla natura dell'appello e, più in generale, al sistema delle impugnazioni nel suo complesso.

Parole chiave: Impugnazioni, riforma del sistema delle impugnazioni, rinnovazione dell'istruzione dibattimentale 


\section{Introduction}

The Italian Code of Criminal Procedure (from now on, the Code) was approved in 1988 and replaced the one approved in 1930. This new Code marked a key turning point in the history of Italian criminal justice, changing the system from an essentially inquisitorial one ${ }^{1}$ to an accusatorial one. However, the appellate system was almost identical to the one envisioned by the previous Code, which provided a wide range of appellate remedies in order to counterbalance the limited guarantees recognized in the first-instance proceedings ${ }^{2}$. Conversely, the new Code, drawn from an accusatorial perspective, was intended to provide greater guarantees during the first-instance proceedings, so that a wide possibility to appeal was less coherent with the system.

Only with the approval of Law no. 46 of 20 February $2006^{3}$ was the matter of the appellate remedies revised, on the one hand by forbidding the public minister and the accused from appealing against the first-instance judgements of acquittal ${ }^{4}$, and, on the other hand, by increasing the cases in which a judgement can be appealed to the Court of Cassation. This reform was then substantially weakened by the intervention of the Constitutional Court, which, by declaring unconstitutional Law no. 46 of 20 February 2006, reintroduced the appeal of the public minister ${ }^{5}$ and of the accused ${ }^{6}$ against the acquittals.

In this context, the need to reform the matter of the appellate remedies became more and more urgent ${ }^{7}$.

For this reason, the appellate system has recently been affected by a reform that has reshaped it. The legislative intervention is characterized by two stages: the first one coincides with the approval of Law no. 103 of 23 June 2017 (from now on, Law

1 More specifically the Code of 1930 was inspired by the biphasic process, which finds its origin in the Napoleonic Code d'instruction criminelle.

2 See Roberto E. Kostoris, 'Le modifiche al Codice di procedura penale in tema di appello e di ricorso per cassazione introdotte dalla c.d. «Legge Percorella»' (2006) Riv. dir. proc. 633.

3 For an articulated study on this legislative reform see Marta Bargis (ed.), Impugnazioni e regole di giudizio nella legge di riforma del 2006 (Giappichelli 2007).

4 Except in some cases specified by law. See Roberto E. Kostoris, 'Le modifiche al Codice di procedura penale in tema di appello e di ricorso per cassazione introdotte dalla c.d. «Legge Percorella»' (2006) Riv. dir. proc. 633, 634.

5 See [2007] Constitutional Court 26.

6 See [2008] Constitutional Court 85.

7 See Marta Bargis and Hervé Belluta, Impugnazioni penali. Assestamenti del sistema e prospettive di riforma (Giappichelli, 2013); Roberto E. Kostoris, 'Le impugnazioni penali, travagliato terreno alla ricerca di nuovi equilibri' (2008) Riv. dir. proc. 915. 
103/2017), which directly modified the Italian Code of Criminal Procedure and provided some directions to the Italian Government for further modifications ${ }^{8}$; the second one is represented by Legislative Decree no. 11 of 6 February 2018 (from now on, Legislative Decree 11/2018), which implemented the aforementioned directions.

This work aims to give a general overview of the appellate remedies in the Italian legal system with a specific focus on the appeal.

\section{Appellate Remedies in Italy: A General Overview}

a) General Profiles. The Italian criminal justice system is structured on three levels: the judges of first-instance, the Courts of Appeal, and the Court of Cassation, which is the apex court that ensures the uniform application of law.

Such structure is only partially reflected by the Italian Constitution (Art. 111 para. 7), which is limited to establishing that it is always possible to recourse to the Court of Cassation for violation of the law against judgments and decisions on personal freedom. So, as it can be seen, the intermediate level between the judges of firstinstance and the Court of Cassation represented by the Court of Appeal is not recognized by the Constitution.

However, the current Code, following a long tradition that comes from the Napoleonic Code d'instruction criminelle and that is typical of the model of the biphasic process, expressly provides the aforementioned three-level structure and sets an articulate system of remedies, to which an entire section is dedicated (Book IX).

The appellate remedies are governed by the principle of taxativity (Art. 568 Code $)^{9}$, pursuant to which the law regulates the cases in which a judicial decision can be appealed and indicates which appellate remedies can be filed against it $^{10}$. However,

8 For an analysis of the changes made by such reform to the Italian criminal justice system see, ex multis, Marta Bargis and Hervé Belluta (ed.), La riforma delle impugnazioni tra carenze sistematiche e incertezze applicative (Giappichelli 2018); Antonia Antonella Marandola and Teresa Bene, La riforma della giustizia penale. Modifiche al codice penale, al codice di procedura penale e all'ordinamento penitenziario (L.103/2017) (Giuffrè, 2017); Adolfo Scalfati (ed.), La riforma della giustizia penale. Commento alla legge 23 giugno 2017, n. 103 (Giappichelli, 2017); Mitja Gialuz, Andrea Cabiale and Jacopo Della Torre, 'Riforma Orlando: le modifiche attinenti al processo penale, tra codificazione della giurisprudenza, riforme attese da tempo e confuse innovazioni' (2017) 3 Riv. trim. - Dir. pen. cont. 173; Marta Bargis, 'Appendice di aggiornamento' in Giovanni Conso, Vittorio Grevi and Marta Bargis (eds.), Compendio di Procedura penale (8th edn, Cedam 2016) 1.

9 See, ex multis, Marta Bargis, 'Impugnazioni' in Giovanni Conso, Vittorio Grevi and Marta Bargis (eds.), Compendio di Procedura penale (8th edn, Cedam 2016) 801, 804.

10 The appealable decisions are judgements, orders and decrees. 
this principle is mitigated in case of judicial decisions on personal freedom and judgements. In fact, such decisions are always subject to appeal to the Court of Cassation, unless they are appealable in another way.

Moreover, there is another type of judicial decision that can be appealed to the Court of Cassation, even if there is not a specific provision. We refer to the case law that provides recourse to the Court of Cassation against so-called 'abnormal' decisions, which have a jurisdictional nature, but whose content is so anomalous that they lie outside the criminal procedural order.

b) The Subjects. The subjects who have the right to appeal are the public prosecutor (Art. 570 Code), the accused (Art. 571 para. 1 Code) ${ }^{11}$ and the lawyer of the accused (Art. 571 para. 2 Code). In addition to these, the Code provides that judicial decisions can also be appealed by the civil party, exclusively with regard to points on civil issues (Art. 576 Code), by the person with civil liability for damages and by the person with civil liability for financial penalties, who may apply for an appellate remedy against the parts of the judgement concerning the liability of the accused and those concerning the restitution, compensation of damages and recovery of the costs of the proceedings (Art. 575 Code).

In order to be entitled to file an appeal, an abstract interest in the correctness of the decision is not sufficient, rather it is necessary that all these subjects have a concrete interest in the removal of the prejudicial effects of the decision ${ }^{12}$.

c) Types of Appellate Remedies. The Italian Code of Criminal Procedure, following a consolidate tradition, provides two kinds of appellate remedies, namely the ordinary ones and the extraordinary ones.

The ordinary appellate remedies can be filed until the decision is final. These remedies are the appeal and the recourse to the Court of Cassation ${ }^{13}$.

11 However, in order to reduce the workload of the Italian Supreme Court, the Law 103/2017 has removed the possibility for the accused of appealing personally to the Court of Cassation (see Art. 613 Code).

12 See on this aspect with regard to procedural law and, more specifically, to criminal procedure Stefania Carnevale, L'interesse ad impugnare nel processo penale (Giappichelli 2013) 1.

13 There are also other ordinary appellate remedies, as the opposition against the decree of conviction (Art. 461 Code), the opposition against the decree of the public prosecutor ordering the restitution of seized objects or rejecting the related request (Art. 263 para. 5 Code), the recourse to the Court of Cassation against the judgement of the Court of Appeal regarding the extradition (Art. 706 Code), the recognition of a foreign judgement (Art. 734 para. 2 Code) or the enforcement abroad of an Italian judgement (Art. 743 para. 4 Code). 
The appeal, as we will see, can be brought before the Court of Appeal against the judgments of first-instance - either convictions or acquittals - and may be based both on substantial grounds and on legal grounds.

Otherwise, the recourse to the Court of Cassation may be lodged against the judgments of appeal, and, with certain limitations, directly against the judgments of first-instance, as well as against all the measures on personal freedom, and may be based on the arguments specified by law (Art. 606 Code).

In addition to such mechanisms, the Italian legal system also provides extraordinary appellate remedies, which can be used to appeal against decisions that have become final.

The first remedy is that of revision, which can be lodged before the Court of Appeal in favor of the convicted person in order to obtain the reopening of the criminal proceedings. This can be used if certain conditions provided by the law are in place, with the purpose of redressing a judicial error (Arts. $629 \mathrm{ff}$. Code). Such a remedy may be lodged only against judgements of conviction, while it is not possible to claim the revision of acquittals (the so-called revision in pejus).

The second remedy is represented by the extraordinary recourse for clerical or factual errors, which can be lodged by the convicted person against final judgments delivered by the Court of Cassation and allows the submission of a request for rectification of a clerical or factual error contained in such decision (Art. 625 bis Code).

The third remedy is that of the rescission of a final judgement, which has recently been reformed by Law 103/2017 and allows the convicted person, who has been absent during all the proceedings, to obtain the removal of a judgment that has become final and the re-opening of criminal proceedings (Art. 629 bis Code).

The fourth remedy is represented by the revocation of the judgement of no grounds to proceed $^{14}$. In particular, such a decision may be appealed by the public prosecutor when new evidence arises or is discovered that, either alone or in addition to the evidence already gathered, may lead to the request for committal to trial (Arts. $434 \mathrm{ff}$. Code).

14 Such decision is pronounced at the end of the preliminary hearing when the judge deems that the accused shall not be committed to trial. 
d) Other Appellate Remedies. Finally, it is worth adding that there are also other appellate remedies against different decisions rendered during the criminal proceedings. We allude to the precautionary measures (both personal and on property), which can be appealed, in case of coercive measure, with the remedy of reexamination, which allows a new evaluation of the facts that justified the issuance of the measure (Art. 309 Code). In all other cases, the precautionary measures can be appealed with the remedy of the appeal (Art. 310 Code).

\section{The Appeal: Preliminary Remarks}

After such an overview, it is worth focusing specifically on the appeal ${ }^{15}$.

The appeal has a hybrid structure. Indeed, it is both an instrument for the control of the first-instance judgment, which may lead to the annulment of the decision, and a remedy that allows, within the limits of the subsections of the decision to which the appeal refers, a new evaluation of the factual and legal aspects of the case addressed by the first-instance judge. It follows that the nature of such an appellate remedy is not perfectly clear, even if the appeal is traditionally considered as an instrument for the control of the first-instance decision, as the cases in which the trial shall be renewed are exceptional ${ }^{16}$.

In the following sections, we will see the main features of the appeal, analyzing the aspects that have been affected by the legislative reforms ${ }^{17}$ and by the case law of both the Court of Cassation and the European Court of Human Rights.

\subsection{The Form of the Appeal}

The Italian Code of Criminal procedure states that both the accused and the public prosecutor are entitled to appeal a judgement ${ }^{18}$. The Legislative Decree 11/2018 reduced the cases in which these subjects may lodge an appeal. In particular, whereas before the legislative reform the conviction could be appealed by both the accused

15 For an analysis of the appeal in the Italian criminal justice before the legislative reforms see, among others, Massimo Ceresa-Gastaldo, ‘Appello (diritto processuale penale)' (2010) III Enc. dir. 11; Giuseppe Di Chiara and Giovanni Tranchina, 'voce Appello (diritto processuale penale)' (1999) II Enc. dir. 200; Paolo Ferrua, 'voce Appello II) Diritto processuale penale' (1988) II Enc. giur. Treccani 1; Giorgio Spangher, 'voce Appello II) Diritto processuale penale' (1991) II Enc. giur. Treccani 1.

16 See, among others, Bargis (n 10) 840-841.

17 For a general overview of the changes to the appeal made by the reform see, among others, Giorgio Spangher, 'Il "nuovo" giudizio di appello' (2017) 10 Dir. pen. proc. 1.

18 Law 103/2017 has reintroduced the possibility for the accused and the public prosecutor to lodge an appeal against judgement of no grounds to proceed, that was repealed by Law 46/2006. 
and the public prosecutor, now such a possibility is accorded only to the accused, while the prosecutor may lodge an appeal against such a decision only when it has established the presence of an aggravating circumstance with special effect or of a penalty of different kind from that provided for the crime (Art. 593 para. 1 Code). Conversely, the power to appeal a judgement of acquittal, which before the reform was accorded without distinctions to both the parties, is now generally recognized to the public prosecutor. Even the accused may lodge an appeal against an acquittal, except when such a decision has ascertained that the criminal act did not occur or the accused did not commit it (Art. 593 para. 2 Code) $)^{19}$.

The appeal shall be lodged within the terms strictly specified by law (Art. 585 Code). The act shall indicate, under penalty of inadmissibility: a) the sections and the subsections of the decision to which the appeal refers; b) the requests, also evidentiary and c) the arguments, with specification of the legal and factual reasons sustaining each request (Art. 581 Code). Law 103/2017 introduced an important specification with regard to the form of the appeal. It provides that, in addition to the elements previously indicated, the appeal shall also contain the evidences which are claimed to be non-existent, have not been gathered, have not been assessed, or have been erroneously evaluated.

The Court of Appeal review is bound by the subsections of the first-instance decision to which the arguments refer (Art. 597 para. 1 Code), but the Court of Appeal can decide independently from such arguments. However, if only the accused appeals, the Court of Appeal cannot reform the judgment of first-instance in a less favorable way for him or her: for example, it cannot impose a more severe penalty or revoke benefits. This is the so called "prohibition of reformatio in pejus" (Art. 597 para. 3 Code).

In the perspective of reducing the length of the proceedings, Law 103/2017 reintroduced the agreement on the arguments for the appeal, which was included in the original version of the $\operatorname{Code}^{20}$ and then repealed in 2008. The new regulation provides that the parties, except in case of serious crimes expressly indicated by the law, may agree on the acceptance, in whole or in part, of the arguments for the appeal and the waiver of other possible arguments. The Court of Appeal is not bound by the

19 Moreover, it must be highlighted that the Legislative Decree 11/2018 has also intervened on another aspect that concerns the legitimacy to appeal. Indeed, the reform has excluded the public prosecutor from the possibility to lodge an incidental appeal.

20 For an analysis of the agreement on the arguments for the appeal in the old Italian Code of Criminal Procedure see Elena Maria Catalano, L’ accordo sui motivi di appello (Giuffrè 2001). 
determinations of the parties, and, consequently, may reject the request. Differently from the previous discipline, there is no automatic reduction of the penalty, which is now decided on a case-by-case basis consistently with the criteria established by the Prosecutor General attached to the Court of Appeal (Art. 599 bis Code) ${ }^{21}$.

\subsection{The Appellate Procedure}

The appellate trial may involve both the merit and the legal profiles of the decision of first-instance. It takes place at a public hearing and the accused is always entitled to participate. After the introductory report by the Judge Rapporteur, each party expresses its conclusions (Art. 602 Code).

The Court of Appeal is normally not entitled to collect new evidence or have the collected evidence recorded and presented again, and decides on the records of evidence already gathered by the judge of first-instance. However, there are some important exceptions to this rule: a) if a party has requested that evidence already gathered during the first-instance trial be taken anew or that new evidence be gathered, the Court orders the renewal of the trial evidentiary hearing ${ }^{22}$ if it deems to be unable to decide on the basis of the available evidence (Art. 603 para. 1 Code); b) the renewal of the trial evidentiary hearing is always ordered when new evidence has been discovered or has arisen after the first-instance judgment (Art. 603 para. 2 Code); c) the renewal may be also ordered ex officio if the Court considers it absolutely necessary (Art. 603 para. 3 Code).

With Law 103/2017 the legislator introduced a new case of renewal of the trial evidentiary hearing. In particular, the appellate judge shall renew the evidencegathering in case of appeal of the Prosecutor against a judgement of acquittal for reasons inherent to the assessment of oral evidence (Art. 603 para. 3 bis Code).

The approval of this rule was justified by the need to comply with the case-law of the European Court of Human Rights (from now on, EtCHR), which, emphasizing the importance of the principles of orality and immediacy, stated that the right to a fair trial enshrined in Article 6 ECHR requires that, "when an appellate court is called upon to examine a case as to the facts and the law and to make a full assessment of

21 See, for an overview of this aspect of the reform, Massimo Ceresa-Gastaldo, 'La riforma dell'appello, tra malinteso garantismo e spinte deflattive' (2017) 3 Riv. trim. - Dir. pen. cont. 163, 170-171; Gialuz, Cabiale and Della Torre (n 10) 173, 187-188.

22 With the expression "renewal of trial evidentiary hearing" we refer to the gathering of evidence at the appellate trial according to the procedures provided for the first-instance trial. 
the question of the applicant's guilt or innocence, it cannot, as a matter of fair trial, properly determine these issues without a direct assessment of the evidence" 23 . According to the European Court, this direct assessment shall be performed when the evidence is decisive for the pronouncement of the judgement.

The ECtHR case law was soon taken up by the Court of Cassation, which highlighted that the Court of Appeal has to renew the gathering of oral evidence if the appellate judge is willing to convict an accused who was acquitted by the judge of first-instance and if such evidence was deemed decisive for pronouncement of the acquittal by this latter judge ${ }^{24}$. In this case, the Court of Appeal applies the same evidentiary rules as the first-instance judge.

The reasons supporting such conclusions are based on the need for criminal responsibility of an accused to be demonstrated "beyond any reasonable doubt". It is a very rigorous standard, which prevents the Court of Appeal from convicting without the direct assessment of oral evidence, consistently with the principles of orality and immediacy, which are all essential elements of accusatorial proceedings ${ }^{25}$.

As it can be seen, the provision introduced by Law 103/2017, differently from what had been indicated by the Court of Cassation, would not seem to refer to the oral evidence being decisive, but to all evidence gathered during first-instance proceedings that are relevant for the ascertainment of criminal liability. In fact, the new regulation states that the appellate judge has the duty to renew the trial evidentiary hearing whenever the public prosecutor lodges an appeal against a first-instance judgment for reasons inherent to the evaluation of the oral evidence.

23 See, among many others, Dan v. Moldova App no. 8999/07 (ECHR, 5 July 2011); and with specific regard to Italy Lorefice v. Italy App. no. 63446/13 (ECHR, 21 June 2017). However, it must be stressed that the European Court has considered that the renewal of the trial evidentiary hearing is not always necessary. Indeed, even if the appeal's conviction is based exclusively on a different evaluation of the written trial's minutes, the proceedings shall be considered fair if the court provides a particularly thorough reasoning for the departing from the assessment given to the evidence by the first-instance judge (see Kashlev v. Estonia App no. 22574/08 (ECHR, 29 April 2016), and, more recently, Chiper v. Romania App no. 22036/10 (ECHR, 13 November 2017)). See on this aspect Michele Caianiello, 'You can't always counterbalance what you want' (2017) 25 European Journal of Crime, Criminal Law and Criminal Justice 283, 285; Ceresa-Gastaldo (n 21) 163,166.

24 Dasgupta [2016] Court of Cassation, Joint Chambers 27620; for an analysis of this judgement see Hervé Belluta and Luca Lupària, 'Alla ricerca del vero volto della sentenza Dasgupta' (2017) 1 Dir. pen. cont. 5. See also Patalano [2017] Court of Cassation, Joint Chambers 18620, which extended the application of the renewal also to the decisions rendered at the end of the summary trial.

25 For an accurate synthesis of the path from EtCHR case law towards the legislative reform see Hervé Belluta and Luca Luparia, 'La parabola ascendente dell'istruttoria in appello nell'esegesi "formante" delle Sezioni Unite' (2017) 3 Riv. Trim. - Dir. pen. cont. 151. 
Such regulation places itself on a long path that is far from being finished. In fact, the Court of Cassation, in its work of shaping the renewal of the trial evidentiary hearing, has specified that the renewal shall be ordered also when a conviction pronounced by the first-instance judge is reformed by the appellate judge into an acquitta ${ }^{26}$.

However, such an issue was then referred to the Joint Chambers of the Court of Cassation $^{27}$, which decided that the appellate judge does not have the obligation to renew the trial evidentiary hearing in case of acquittal in appeal following the conviction pronounced by the first-instance judge, but that he/she only has the duty of thoroughly explaining the reasons for the departure from the assessment given to the evidence by the first-instance judge. The reason for such different evaluation is that the acquittal, unlike the conviction, has not to be proven beyond any reasonable doubt, so that it is not necessary to renew the evidence-gathering. Moreover, admitting the renewal of evidence gathering also in case of reversal from conviction to acquittal would be likely to result in considering the appellate trial as a restatement of the firstinstance trial, with obvious consequences on the length of the proceedings ${ }^{28}$.

In the same decision, the Joint Chambers of the Court of Cassation, in clarifying the content of the regulation introduced with Law 103/2017, also stated that the appellate judge does not have the duty to renew the gathering of all the evidence, but only of the oral evidence, which, being specifically contested by the public prosecutor, was erroneously evaluated by the first-instance judge and was deemed decisive for the judgement. In this way, the Supreme Court has brought the new regulation into line with its previous case law.

This is a very complex framework, which is characterized by multiple judicial interventions ${ }^{29}$ and which demonstrates the difficulties of defining the nature of the appeal and the scope of the appellate trial.

26 Marchetta [2017], Court of Cassation, Chamber II 41571. See Natalia Rombi, 'La riforma di una sentenza di condanna esige la rinnovazione della prova dichiarativa in appello?' (2018) 1 Proc. pen. e giust. 106.

27 In the Italian legal system, the Joint Chambers of the Court of Cassation have the duty to settle judicial disagreements between the Chambers of the Court of Cassation and to decide issues of special importance.

28 Troise [2018] Court of Cassation, Joint Chamber 14800. For a comment to this judgement see Novella Galantini, 'La riassunzione della prova dichiarativa in appello: nota a margine di Sezioni Unite Troise' (2018) Dir. pen. cont. 1 https://www.penalecontemporaneo.it/upload/6905-galantini2018a.pdf accessed 12 May 2018.

The judicial work of shaping the renewal of evidence-gathering is far from being finished, even after the legislative reform. See, for example, [2017] Court of Cassation, Chamber II 55068, which clarified that the appellate judge has not the duty to renew the gathering of the oral evidence that is deemed decisive, when it was ascertained that the witness was subject to bribery, provided that there are no elements that indicate a subsequent modification of such condition. 


\subsection{The Types of Decision Delivered by the Appellate Judges}

Finally, the different outcomes of the appellate trial should briefly be mentioned.

If the Court of Appeal considers the appeal to be inadmissible, for example because of a formal defect of the act, it pronounces a judgement of inadmissibility (Art. 591 Code). Conversely, if the Court considers the appeal to be unfounded on merit, the appellate judge shall confirm the decision of first-instance. Moreover, if the Court grants the appeal, totally or partially, the Court amends the decision of first-instance (Art. 605 Code). Finally, if the Court detects certain causes of nullity of the first-instance trial ${ }^{30}$, it declares the nullity of the decision and orders that the case file be forwarded to the first-instance judge for a new trial (Art. 604 Code).

\section{Conclusive Remarks}

The topic of the appeal is a very vital and relevant issue in Italy today. The most sensitive issues are represented, on one hand, by the nature of the appellate trial, and, on the other hand, by the need to ensure a reasonable length of the proceedings.

From the first point of view, despite the clarifications of the Court of Cassation, which limited the scope of the renewal of the trial evidentiary hearing introduced with Law 103/2017, the nature of the appellate trial is still a controversial issue, as it is constantly on the edge between a control on the correctness of the judgment of the first-instance judge and a restatement of the first-instance trial ${ }^{31}$.

In this context, it is worth highlighting that the regulation of the appeal is subject to a constant work of remodeling by the Court of Cassation, whose outcomes are not always foreseeable.

From the second point of view, i.e. with regard to reasonable duration of the proceedings, the reduction of the cases in which the accused and the public prosecutor may appeal, on one hand, and the introduction of the agreement on the arguments of the appeal, on the other hand, seek to shorten the length of the proceedings, which in Italy is a very sensitive issue.

30 For example, when the accused was convicted for a different criminal act.

31 See, on this aspect, Antonia Antonella Marandola, 'Prime riflessioni sul "nuovo" giudizio d'appello' (2018) 2 Dir. pen. cont. 159, 174. 


\section{Bibliography}

Marta Bargis, 'Appendice di aggiornamento' in Giovanni Conso, Vittorio Grevi and Marta Bargis (eds.), Compendio di Procedura penale (8th edn, Cedam 2016) 1

Marta Bargis, 'Impugnazioni' in Giovanni Conso, Vittorio Grevi and Marta Bargis (eds.), Compendio di Procedura penale (8th edn, Cedam 2016) 801

Marta Bargis (ed.), Impugnazioni e regole di giudizio nella legge di riforma del 2006 (Giappichelli 2007)

Marta Bargis and Hervé Belluta, Impugnazioni penali. Assestamenti del sistema e prospettive di riforma (Giappichelli, 2013)

Marta Bargis and Hervé Belluta (ed.), La riforma delle impugnazioni tra carenze sistematiche e incertezze applicative (Giappichelli 2018)

Hervé Belluta and Luca Lupària, 'La parabola ascendente dell'istruttoria in appello nell'esegesi "formante" delle Sezioni Unite' (2017) 3 Riv. trim. - Dir. pen. cont. 151

Hervé Belluta and Luca Lupària, 'Alla ricerca del vero volto della sentenza Dasgupta' (2017) 1 Dir. pen. cont. 5

Stefania Carnevale, L'interesse ad impugnare nel processo penale (Giappichelli 2013)

Michele Caianiello, 'You can't always counterbalance what you want' (2017) 25 European Journal of Crime, Criminal Law and Criminal Justice 283

Elena Maria Catalano, L' accordo sui motivi di appello (Giuffrè 2001)

Massimo Ceresa-Gastaldo, 'Appello (diritto processuale penale)' (2010) III Enc. dir. 11

Massimo Ceresa-Gastaldo, 'La riforma dell'appello, tra malinteso garantismo e spinte deflattive' (2017) 3 Riv. trim. - Dir. pen. cont. 163

Paolo Ferrua, 'voce Appello II) Diritto processuale penale' (1988) II Enc. giur. Treccani 1

Giuseppe Di Chiara and Giovanni Tranchina, 'voce Appello (diritto processuale penale)' (1999) II Enc. dir. 200

Novella Galantini, 'La riassunzione della prova dichiarativa in appello: nota a margine di Sezioni Unite Troise' (2018) Dir. pen. cont. 1 https://www.penalecontemporaneo.it/upload/6905-galantini2018a.pdf accessed 12 May 2018

Mitja Gialuz, Andrea Cabiale and Jacopo Della Torre, 'Riforma Orlando: le modifiche attinenti al processo penale, tra codificazione della giurisprudenza, riforme attese da tempo e confuse innovazioni' (2017) 3 Riv. trim. - Dir. pen. cont. 173

Roberto E. Kostoris, 'Le impugnazioni penali, travagliato terreno alla ricerca di nuovi equilibri' (2008) Riv. dir. proc. 915

Roberto E. Kostoris, 'Le modifiche al Codice di procedura penale in tema di appello e di ricorso per cassazione introdotte dalla c.d. «Legge Percorella»' (2006) Riv. dir. proc. 633

Antonia Antonella Marandola and Teresa Bene, La riforma della giustizia penale. Modifiche al codice penale, al codice di procedura penale e all'ordinamento penitenziario (L.103/2017) (Giuffrè, 2017)

Antonia Antonella Marandola, 'Prime riflessioni sul "nuovo" giudizio d'appello' (2018) 2 Dir. pen. cont. 159, 174.

Natalia Rombi, 'La riforma di una sentenza di condanna esige la rinnovazione della prova dichiarativa in appello?' (2018) 1 Proc. pen. e giust. 106

Adolfo Scalfati (ed.), La riforma della giustizia penale. Commento alla legge 23 giugno 2017, n. 103 (Giappichelli, 2017)

Giorgio Spangher, 'Il "nuovo" giudizio di appello' (2017) 10 Dir. pen. proc. 1

Giorgio Spangher, 'voce Appello II) Diritto processuale penale’ (1991) II Enc. giur. Treccani 1 